DOI: $10.24193 /$ tras.SI2021.5

Published First Online: 12/15/2021

\section{INSTITUTIONAL DYNAMICS AND \\ ECONOMIC RESILIENCE IN CENTRAL \\ AND EASTERN EU COUNTRIES. \\ RELEVANCE FOR POLICIES ${ }^{\star}$}

\section{Gabriela-Carmen PASCARIU \\ Andreea IACOBUȚĂ-MIHĂIȚ̆ \\ Carmen PINTILESCU \\ Ramona ȚIGĂNAȘU}

\section{Abstract}

In the global context generated by the 2008-2009 economic crisis and by the current COVID-19 pandemic, the analysis of the way in which territories can resist, return and adapt to shocks has become a priority for resilience-based policies. The paper aims to investigate the role of institutions in economic resilience, in the particular case of Central and Eastern European countries since, despite the ongoing convergence process, the institutional gaps and weaknesses of these states challenge their possibilities to recover after this health crisis, as well as to improve their resilience capacity. The methodological approach involves, firstly, a cross-country time-series panel regression, using the annual data from 1996 until 2019. Secondly, we applied the principal component regression, in order to capture the country specificities. The research focuses on the linkages between institutional dynamics and economic resilience, an issue less reflected in literature. Our results confirm the influence of institutional factors on economic resilience and, more importantly, it is highlighted that the 'one size fits all' principle does not apply in the case of recovery and resilience programs, which is due to the fact that institutions act differently, depending on various socio-economic and political contexts.

Keywords: Central and Eastern European Countries, institutions, resilience, National Recovery and Resilience Plans.
Gabriela-Carmen PASCARIU (corresponding author)

Professor, Centre for Research in International Economic Relations and European Studies, Faculty of Economics and Business Administration, Alexandru Ioan Cuza University, Iași, Romania Tel.: 0040-232-201.318

E-mail: gcpas@uaic.ro

\section{Andreea IACOBUȚĂ-MIHĂIȚĂ}

Professor, Centre for Research in Economics and Business Communication, Faculty of Economics and Business Administration, Alexandru loan Cuza University, Iași, Romania E-mail: andreea.iacobuta@uaic.ro

\footnotetext{
* Acknowledgement. This work was supported by a grant of Ministery of Research and Innovation, CNCS-UEFISCDI, project number PN-III-P4-ID-PCCF-2016-0166, within PNCDI III project 'ReGrowEU - Advancing ground-breaking research in regional growth and development theories, through a resilience approach: towards a convergent, balanced and sustainable European Union'.
}

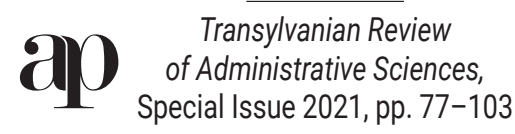




\section{Carmen PINTILESCU}

Professor, Department of Accounting,

Economic Informatics and Statistics,

Faculty of Economics and Business Administration,

Alexandru loan Cuza University, lași, Romania

E-mail: carmen.pintilescu@uaic.ro

\section{Ramona ȚIGĂNAȘU}

Researcher, Centre for European Studies, Faculty of Law,

Alexandru loan Cuza University, Iași, Romania

E-mail: ramona.frunza@uaic.ro

\section{Introduction}

The concept of resilience is almost fifty years old. Initially introduced in ecological science (Holling, 1973) and in psychology (Anthony, 1974), resilience thinking was soon extended to any socio-ecological system (Batabyal, 1998; Carpenter et al., 2001) and currently represents a key concept in many areas, such as: regional science, economics and economic geography (Di Caro, 2014; Martin and Sunley, 2015); territorial and urban planning (Magoni, 2017; Banică et al., 2020); social sciences (Linnel, 2014; Cheshire, Esparcia and Shucksmith, 2015); political science (Bourbeau, 2015; Martin and Roman, 2021).

In the last years, in the global context characterized by an increasing number of more and more various crises, of marked instability and consequent increase in opportunity costs, the scientific research on resilience has intensified (i.e., resilience was a key concept in 21 Clarivate-indexed papers in 1999, in 444 papers in 2000, in 2,555 papers in 2010 and in 16,355 papers in 2020); moreover, the resilience concept was rapidly 'absorbed' by public policies in all the countries of the world. The European Union holds the top position in this trend, the acquis communautaire including the word 'resilience' grew from 6 documents in 1990 to 186 in 2010 and to 1,127 in 2020 (Official Journal of the European Union, 1990-2021). Through its short-term social, economic and political impact, i.e. overcoming the crisis, as well as through its long-term one, i.e. sustainable development, convergence and conditionalities determined by the European Green Deal, the COVID-19 pandemic has clearly reinforced resilience-based policies, which is mainly reflected in the Next Generation EU Plan (European Commission, 2020a). Until 2026, more than $€ 800$ billion will be invested in EU Member States mainly through 'The Recovery and Resilience Facility' (the Facility) within the National Recovery and Resilience Plans (NRRPs). By promoting 'a greener, more digital, more resilient', more equal, safer and healthier development (European Commission, 2019), the main objective is to make sure that Member States' economies do not only recover after the crisis generated by the Coronavirus pandemic but manage to reach a level above the one prior to the crisis. In literature, such a perspective on resilience is proposed by the 'evolutionary approach', according to which resilience does not only imply the capacity of a system to recover its 
functions, employment and prosperity ('bounce back') and return to the initial equillibrium (JRC-EC, 2015) but also to engage in structural transformations and adaptive processes focused on reaching a new balance and a more performant development model ('bounce forward') (Reggiani, De Graaff and Nijkamp, 2002).

From the European governance perspective, a fundamental question arises, i.e. to what extent do Member States have the capacity to efficiently implement these plans and to consequently become more resilient in facing the current and forthcoming challenges, transforming, eventually, their socio-economic systems in line with the development perspectives recently reflected in the EU Green Deal? Which are the factors that this transformative capacity depends on and how can these be capitalized on? Which are the main triggers of resilience, in various contexts and for different types of shocks? Can new structural, territorial, social and economic disparities, bearing long-term risks for the integration process, result from this? These questions are more relevant in the case of Central and Eastern European countries confronted with weak institutions which may have a negative impact on the implementation of NRRPs.

Unfortunately, despite the fact that, for more than thirty years, an extremely rich literature on resilience drivers and a wide agreement of the strong interdependence between institutions and development have been in place (North, 1990; Acemoglu, Johnson and Robinson, 2004), for a long period, resilience literature has paid little attention to the role of institutions and of the governance system (Swanstrom, Chapple and Immergluck, 2009; Bristow, 2010), thus significantly diminishing the explanatory power of the resilience theory. Moreover, despite the fact that, at the EU level, solid economic structures and institutions are considered essential for countries' economic resilience and long-term prosperity (European Central Bank, 2016), the institutional approaches in relation with the differences in resilience performance and/or capacity of the EU Member States are hardly reflected in the literature and even less in the current NRRPs.

Consequently, the aim of this paper is to analyze the importance of the institutional dimension for economic resilience and to identify the key institutional drivers in the resilience performance for the 11 CEECs (Poland, Romania, Bulgaria, Hungary, Latvia, Lithuania, Estonia, Croatia, the Czech Republic, Slovenia and Slovakia). The institutional dimension is assessed by using the six governance indicators released by the World Bank namely, Voice and accountability, Political stability and absence of violence/terrorism, Government effectiveness, Regulatory quality, Rule of law, Control of corruption. For assessing economic resilience, we used the most common indicators from the literature, namely the GDP growth rate (\%) and the Employment rate (\%). The analysis covers the 1996-2019 period, long enough to highlight the institutional dynamics and its impact on the economic resilience when a deep shock occurs.

Key conclusions with normative relevance for resilience-based policies from the institutional thinking perspective will be provided. First of all, the methodological approach implies a cross-country time-series panel regression, using the annual data from 1996 until 2019 and, secondly, in order to capture the country specificities, a 
principal component regression. The paper is structured as follows: in Section 2 we provide a survey of the literature on economic resilience and the institutional dimension. Section 3 introduces the data and the methodology used for the estimation of economic resilience. In Section 4, we present the empirical analysis for the 11 CEECs; the last section presents the main conclusions.

\section{Literature review}

In the economic development studies, resilience could reflect the capacity of a socio-economic system (city, region, country) to be placed on a long-term development path, incorporating a large set of internal and external conditionalities (Martin and Sunley, 2015; Cellini and Torrisi, 2014; Suzuki and Nijkamp, 2017). As such, resilience analysis can outline the vulnerabilities within a system in relation to various types of shocks (natural disasters, climate change, social and economic crises, wars etc.), which may further explain its capacity to resist, recover and transform by adopting a new growth and development pattern. Thus, the resilience analysis of a system can generate findings that have a highly strategic relevance for policy making. From this perspective, conceptual clarifications and a deeper understanding of the drivers of resilience are required, considering the multitude of sometimes contradictory approaches in literature.

Since a detailed analysis of the multiple conceptual delimitations is beyond the purpose of this paper, we will limit our exemplification to Foster (2007, p. 14) who defines resilience 'as the ability of a region to anticipate, prepare for, respond to, and recover from a disturbance'. Also, Hill, Wial and Wolman (2008, pp. 4-5) consider resilience as 'the ability of a region to recover successfully from shocks to its economy that either throw it off its growth path or have the potential to throw it off its growth path but do not actually do so', while in Briguglio's et al. study (2008, p. 5), economic resilience is defined as 'the policy-induced ability of an economy to recover from or adjust to the negative impacts of adverse exogenous shocks and to benefit from positive shocks'.

The complexity of the concept primarily derives from the multitude of interconnected factors that influence resilience. For example, Hill, Wial and Wolman (2008, pp. 9-10) consider that there are three main explanations for economic resilience: governance responses, industry or firm responses and the way in which institutional characteristics (including institutional structure, institutional history, and institutional culture) respond to economic shocks. Bristow et al. (2014) argue in favor of the existence of four categories of factors which provide specificity at the regional level while influencing resilience to economic shocks, i.e.: businesses, economy and the business environment, people and the population, place-based characteristics, and community and societal characteristics. Healy's analysis model (2020, p. 10) is in line with the above mentioned study, with the difference that the fourth category is clearly named 'institutions' and that the role of policy-making is discussed separately, with a stress on the influence it exerts on the other categories. 
Moreover, an increasing body of literature emphasizes the role of institutions as 'the rules of the game in a society or, more formally, are the humanly devised constraints that shape human interaction (...) they structure incentives in human exchange, whether political, social, or economic' (North, 1990, p. 3) in understanding and reinforcing economic resilience (Acemoglu et al., 2003; Sonderman, 2017). The study of Briguglio et al. (2008) points to the fact that good governance is essential for the appropriate functioning of an economic system and can, moreover, contribute to the consolidation of its resilience. Sonderman (2017) also brings arguments in favor of the role that the quality of institutions plays in the capacity of an economy to absorb shocks and empirically demonstrates that the probability of a severe economic crisis is significantly reduced in a flexible and adaptable institutional environment.

The interference between the institutionalist theory and resilience analysis becomes even more relevant from the evolutionist perspective. The integration of institutional change processes and their endogenous causes, of some phenomena such as path dependency, of lock-in within the economic resilience analysis can certainly contribute to the further improvement and development in the field (Sjöstedt, 2015).

Nevertheless, in various studies, institutions have an integrated, horizontal conditionality on resilience. For example, the European Central Bank study outlines two aspects of resilience: ex-ante and ex-post. The ex-ante resilience refers to the capacity of an economy to resist to a shock, while the ex-post resilience refers to the capacity of an economy to recover rapidly, with moderate costs, after a shock. In the ex-ante stage, the magnitude and depth of a recession or crisis depend on the institutional framework of that particular country (ECB, 2016, p. 9). Consequently, understanding the role of institutions (both formal and informal) in increasing the resilience of socio-ecological systems and of their interdependence is essential for sustainable development; however, the key question which arises is 'what institutional arrangements are more convenient for enhancing resilience?'. Informal institutions are generally strong but flexibile formal institutions better support the various systems' adaptability to changes.

Thus, the key conclusion is that the identification and assessment of resilience-favorable institutions must be carried out by taking into account the specificity of the systems and conditions they evolve in. Therefore, we consider that an analysis of the impact that institutional factors have on economic resilience, especially focused on the role of the institutional dynamics, is most appropriately carried out on the former communist countries in Central and Eastern Europe.

The way these economies reacted to the 'shock' produced by the change of the system must be taken into account. Once the communist regime collapsed, CEECs implemented various types of reforms according to which they can be grouped in: countries which adopted the shock therapy (Poland), countries which preferred gradualism (Romania, Bulgaria), and countries with a stable progressive development (Estonia, Slovenia, Czech Republic) (Frunză, 2011; Țigănașu, Pascariu and Baciu, 2014). Therefore, some countries were inspired and brave enough to take advantage 
of the opportunity provided by the fall of the totalitarian system which they capitalized on by implementing measures aimed to build a society based on economic liberalism (Socoliuc, 2014), while others lagged behind due to persistent corruption, bureaucracy and inefficiency which obstructed development. Nevertheless, these measures explain only to a limited extent why some countries were successful while others failed. Beyond the rhythm and sequence of reforms, other country specific factors (for example, initial conditions, the ideological values of transition governments, people's values and attitudes) (Iacobuță, 2012) should be considered in order to explain the different economic results of the transition countries.

The economic dynamic in this part of Europe can also be explained by the way in which history conveyed its messages and effects in time (Vlăsceanu, p. 112); moreover, in these countries, institutional development was marked by the path dependency which essentially states that history is extremely important and that systems can never break with the past entirely. Therefore, the institutions' reconstruction process coexisted with the old structure-specific inertia as well as with the perpetuation of obsolete mentalities (Frunză, 2011). It should also be noted that, while the integration process contributed to the economic growth of these countries, it did not necessarily manage to reduce the gaps between them because results depend on the specific conditions of every country, on the business environment attractiveness, stability, good governance, etc., essentially on the institutional systems' quality and on the way these interfere in different contexts (Țigănașu, Pascariu and Baciu, 2014).

In this context, an analysis of the way institutional dynamics influences economic resilience becomes extremely important in the case of CEECs since the institutional gaps and weaknesses of these countries challenge their possibilities to recover after a crisis as well as to improve their resilience capacity, with high relevance for the successful implementation of the NRRPs.

\section{Data and methodology}

In this paper, we analyze the economic resilience for 11 CEECs, members of the EU, through an institutional approach. The sources for the data used in the analysis are the World Bank (Worldwide Governance Indicators and World Development Indicators) and the Heritage Foundation. The time period concerns the years 1996-2019. Some missing values were replaced by simple imputation methods.

For assessing economic resilience, we have used indicators reflecting the economic growth and the labor market. For economic growth we selected the GDP growth rate (\%) (i.e., the annual percentage growth rate of GDP at market prices), an adequate measure of resilience since it indicates how fast the economy is growing or falling. Besides, as shown in the existing literature (Cellini and Torrisi, 2014) and applicable to our study, a GDP measure may better capture the economic fluctuations since some of the countries in our sample display a greater institutional rigidity. The rationale for focusing also on the labor market is related to the fact that the impact of 
a crisis is particularly strong in such markets since, in order to reduce costs, companies will adjust their labor force (Fingleton, Garretsen and Martin, 2012). In line with several recent studies, we use the employment rate (\%) to capture the labour market conditions due to the issues raised by the use of unemployment data (Pintilescu and Viorică, 2019; Kitsos and Bishop, 2018).

The empirical research has two parts. In the first part, due to the short time period of data, we have used the panel data analysis and in the second part, in order to identify the country specific effects, we have applied the principal component regression. For panel data estimations, in terms of specification, we have chosen, as control variables, two components of the government size category from the Heritage Foundation Index of Economic Freedom, the tax burden and the government spending, and the open markets pillar (from the same index) which includes the trade freedom, investment freedom and financial freedom. The Hausman test has been applied to add fixed or random effects and, according to the results of this test, we have estimated a simple pooled OLS model with country fixed effects.

The econometric specifications used for panel data is as follows:

$$
\begin{aligned}
& G D P_{i, t}=\beta_{0}+\beta_{1} \text { Voice }_{i, t}+\beta_{2} \text { Regul }_{i, t}+\beta_{3} \text { Govern_ef }_{i, t}+\beta_{4} \text { Polit_stab }_{i, t}+\beta_{5} \text { Rule_law }_{i, t}+ \\
& \beta_{5} \text { Corrupt }_{i, t}++\beta_{5} \text { Govern_size }_{i, t}+\beta_{6} \text { Open_markets }_{i, t}+\varepsilon_{i, t} \\
& \text { Empl }_{i, t}=\beta_{0}+\beta_{1} \text { Voice }_{i, t}+\beta_{2} \text { Regul }_{i, t}+\beta_{3} \text { Govern_eff }_{i, t}+\beta_{4} \text { Polit_stab }_{i . t}+\beta_{5} \text { Rule_law }_{i, t}+ \\
& \beta_{5} \text { Corrupt }_{i, t}++\beta_{5} \text { Govern_size }_{i, t}+\beta_{6} \text { Open_markets }_{i, t}+\varepsilon_{i, t}
\end{aligned}
$$

where $G D P_{i, t}$ is the GDP growth rate (\%) and $E m p l_{i, t}$ is the Employment rate (\%).

The coefficients $\beta_{i}, i=1,2,3,4,5,6$ are the coefficients associated with the explanatory variables and the term $\varepsilon$ is the error term, $i$ indicates the countries and $t$ the time period.

For principal component regression, we first applied the principal component analysis in order to extract the factors that explain the most important variance of the variables. The selection of factors is based on Kaiser's criteria, which corresponds to eigenvalues greater than 1 , and on the percentage of variance explained by each factor. The factors extracted were then used as explanatory variables in the econometric models, considering the same two measures for economic resilience, GDP growth rate and Employment rate, as dependent variables.

\section{Empirical analysis}

The analysis presented in this section highlights the institutional dynamics in CEECs in relation with the economic dynamics reflected through GDP and employment, as key indicators for reflecting the economic resilience performance. 


\subsection{Dataset description}

In terms of institutional dynamics, the literature is highly divided between the 'path dependency' perspective, the institutions' stability and rigidity (particularly in the case of the informal ones) and the evolutionist perspective, i.e., of institutional transformation as a reaction to various stressors or alteration of the social, economic or political context through reforms (Pascariu and Țigănaşu, 2017).

Looking at the CEECs, based on the institutional indicators included in our analysis, we first found a high institutional instability. Given the fact that all CEECs, particularly Estonia, Latvia, Lithuania (Figure 7, Annex 1), registered significant GDP falls in the first year after the onset of the crisis, we are obviously wondering whether, prior to the $2008 / 2009$ crisis, there had been an institutional deterioration associated with a low resistance capacity in these countries. Regarding the institutional dynamics, beyond existing differences, we generally observe a positive evolution in the period before the crisis in terms of Political stability (Figure 2, Annex 1), of Regulatory quality (Figure 4, Annex 1), Rule of law, while Government effectiveness (Figure 3, Annex 1), Voice and accountability (Figure 1, Annex 1) and Control of corruption (Figure 6, Annex 1) have deteriorated. After the crisis, the most unfavorable evolution was registered in terms of Voice and accountability (except Estonia), Political stability (except Estonia, Croatia and Lithuania). It is also worth mentioning the fact that, as a whole, the institutional climate in CEECs improved during the period under analysis (except in Hungary and Poland), particularly in terms of Regulatory quality, Rule of law, Government effectiveness and Control of corruption although, in most cases, the values prior to the crisis were not reached, thus reflecting a low level of institutional resilience.

High heterogeneity is another important observation deriving from the analysis of the linkages between institutional dynamics and economic dynamics. A pattern able to cluster these countries based on the quality of institutions or economic performance could not be identified; consequently, a detailed country-analysis, whose conclusions are illustrated in 4.3 , became necessary.

Moreover, given the fact that economic growth rates did not reach the levels before the crisis, we notice that the instability of institutions and their low resilience occurred not only in relation with CEECs' limited capacity to resist to shocks but also with their limited recovery capacity. The evolution of the GDP growth rate in CEECs between 1996-2019 was clearly related, at least during the first stage, to the market economy transition process and to the reforms undertaken with this purpose by each country. The integration process also implied institutional transformations and economic restructuring adapted to the already existing national models. Hence, the heterogeneity of the situations which followed the severe economic downturn in the early 1990s and which were further reflected during the 2008/2009 crisis (Iacobuță, Asandului and Căutișanu, 2020). Overall, the GDP growth rate significantly declined from 2008 to 2009 and, in the post-crisis period, the evolution is, in most cases, positive although it has not reached the pre-crisis level, except in the case of Hungary. 
Also, the labor market proved highly resilient and absorbed the shock without any effects on its growth tendency: at the end of the period under analysis, all CEECs registered employment levels above the ones before the crisis. In correlation with the GDP dynamics, it is shown that the economic growth was rather extensive than productivity-based which points to the fact that the growth model was not more efficient and, consequently, implied no improvement in terms of resilience capacity.

\subsection{Panel data estimations}

According to Hausman test results, we estimated a simple pooled OLS model with country fixed effects, taking into account the GDP growth rate (\%) and Employment rate $(\%)$ as dependent variables (Table 1$)$. We chose this model to capture heterogeneity between countries through the individual intercept value.

Table 1: Coefficients for the panel data estimations using as dependent variables GDP growth rate (\%) and Employment rate (\%)

\begin{tabular}{|c|c|c|}
\hline Variables & $\begin{array}{l}\text { Model with } \\
\text { GDP growth rate }\end{array}$ & $\begin{array}{c}\text { Model with } \\
\text { Employment rate }\end{array}$ \\
\hline Constant & $\begin{array}{c}3.402 \\
(2.423)\end{array}$ & $\begin{array}{l}78.945^{\star \star \star} \\
(1.341)\end{array}$ \\
\hline Voice and accountability & $\begin{array}{l}-0.707 \\
(1.831)\end{array}$ & $\begin{array}{l}-10.402^{\star \star \star} \\
(1.105)\end{array}$ \\
\hline Regulatory quality & $\begin{array}{l}-0.309 \\
(1.501)\end{array}$ & $\begin{array}{c}0.062 \\
(0.807)\end{array}$ \\
\hline Government effectiveness & $\begin{array}{c}1.896 \\
(1.822)\end{array}$ & $\begin{array}{l}1.529^{\star} \\
(0.894)\end{array}$ \\
\hline Political stability & $\begin{array}{l}2.173^{\star \star} \\
(1.108)\end{array}$ & $\begin{array}{l}-1.990 * \star \\
(0.520)\end{array}$ \\
\hline Rule of law & $\begin{array}{l}-9.353^{\star \star \star} \\
(1.995)\end{array}$ & $\begin{array}{l}6.057 * \star \star \\
(0.989)\end{array}$ \\
\hline Control of corruption & $\begin{array}{l}5.898^{\star \star *} \\
(1.605)\end{array}$ & $\begin{array}{l}2.183^{\star \star} \\
(0.786)\end{array}$ \\
\hline Government size & $\begin{array}{l}-0.006 \\
(0.018)\end{array}$ & $\begin{array}{c}0.003 \\
(0.009)\end{array}$ \\
\hline Open markets & $\begin{array}{c}0.024 \\
(0.025)\end{array}$ & $\begin{array}{l}-0.0008 \\
(0.013)\end{array}$ \\
\hline Adjusted $\mathrm{R}^{2}$ & 0.106 & 0.851 \\
\hline F-statistic & 2.735 & 84.641 \\
\hline Observations & 264 & 264 \\
\hline \multicolumn{3}{|c|}{ Standard errors in parentheses. ${ }^{* *} p<0.01 ; * * p<0.05 ; * p<0.1$. } \\
\hline
\end{tabular}

The estimations show the statistically significant influence of Political stability, Rule of law, and Control of corruption on the GDP growth rate. Political stability, and Control of corruption react positively to increasing GDP growth rate among CEECs, while the Rule of law has a negative influence. For Employment rate, estima- 
tions show a significant statistical influence of Voice and accountability, Government effectiveness, Political stability, Rule of law, and Control of corruption. Voice and accountability, and Political stability have a negative influence on Employment rate, while Government effectiveness, Rule of law, and Control of corruption have a positive influence.

According to our results, the institutions under analysis in this research have a stronger impact on the labor market than on the economy, as a whole. Voice and accountability has a negative impact on the GDP and Employment rate although statistically insignificant on GDP. The explanation may reside in the fact that, in these countries, where systems were adapted to an autocratic rather than democratic regime, reforms acted as a shock. For example, Sirowy and Inkeles (1990) mention an untrade-off between democracy and economic growth which seems to apply in the CEECs' case. Under the impact of integration, these countries rapidly adopted democratic reforms by pushing governments towards growth-oriented policies with negative effects on the labor market which is, generally, a rigid one. In countries with a long history under authoritarian regimes, democratic systems' implementation is generally associated with a period of reduced public policies' effectiveness. As for Political stability and Control of corruption, our GDP analysis shows that they both encourage investments, capital accumulation, business development and quality of institutions and that they have a strong direct effect (Samarasinghe, 2018). Unlike Control of corruption, which has a constant positive impact on the labor market, Political stability has a negative one. One possible explanation for this may be in the fact that, in these countries, political parties are still young, with a rather fluctuant electorate and, once in power, they try to hold on to it (i.e., the electorate) by complying with salary claims, by raising the minimum wage, by granting various social benefits and incentives to companies for hiring certain social groups, thus stimulating the labor market and triggering positive effects on employment. In a context of political stability, these benefits are no longer granted and the effect on employment becomes negative. Finally, the Rule of law provides predictability on the labor market and stimulates employment but, at the same time, the induced institutional rigidity reduces the capacity of the economy to find bottom-up solutions, to innovate and create new institutions in real time when the old ones prove inefficient in case of a shock and, in this case, the relation with the economic dynamics is a negative one. Although it strengthens the resistance of the system, the rule of law limits recovery opportunities.

Obviously, beyond these general results, we find situations which are specific to each country. In order to test the null hypothesis of homogenous coefficients in the panel structure, we perform the Wald test. The results obtained show the presence of heterogeneity for the estimated models. Due to the countries' heterogeneity, we will continue our analysis using country-specific estimations. 


\subsection{Country-specific estimations}

For the identification of the country-specific characteristics, we applied principal component regression. We chose this method in order to avoid the multicollinearity between variables. We first performed a principal component analysis (PCA) in order to select the factors that explain the most important part of the variance of statistical variables.

The selection of factors is based on Kaiser's criteria, which corresponds to eigenvalues greater than 1 , and on the percentage of variance explained by each factor. The variables that explain these factors were selected according to their factor loadings, higher than 0.7 . The factors extracted were then used as explanatory variables in the econometric models, considering the GDP growth rate and Employment rate as dependent variables.

\subsubsection{Selection of the factors}

By applying PCA and using VARIMAX as a method of rotation of the axes, we extracted the factors that explain the most important part of the variance of statistical variables. Put otherwise, institutions were grouped depending on the annual amplitude of the statistical variance, with F1 including factors with the highest instability and F2 including factors with the lowest instability (Table 2). In the next stage, by using regression analysis, we could determine those institutions which play a key role in economic resilience, thus correlating the institutions' dynamics with economic dynamics and enabling the assessment of the resilience of countries under analysis during the 2008/2009 crisis from a new perspective, which has not been specifically dealt with so far in the literature.

According to the data in Table 2, instability was the main characteristic of the institutional systems in these countries in the period under analysis. For the majority of countries, most of the analyzed variables cluster in Factor 1 (with strong annual variations): Regulatory quality (9 countries), Rule of law (8 countries), Government effectiveness (7 countries) and, to a lower extent, Voice and accountability (6 countries). Political stability and Control of corruption were relatively more stable. The analysis also highlights the heterogeneity of institutional transformations in these countries, which points to the importance of adopting 'institutions-sensitive' policies in resilience-based approaches, particularly when significant conditionality on the economic system is identified. In order to assess these conditionalities and to consequently evaluate the extent to which the identified factors have an impact on economic resilience as well as how powerful the interdependecies between institutional and economic dynamics are in each analyzed country, Factor 1 and Factor 2 were included in the regression analysis as explanatory variables for both GDP growth rate and Employment rate. 
Table 2: Factors loadings for the factors extracted by applying PCA

\begin{tabular}{|c|c|c|c|c|c|c|c|}
\hline Countries & $\begin{array}{l}\text { Factors } \\
\text { extracted }\end{array}$ & $\begin{array}{c}\text { Voice and } \\
\text { accountability }\end{array}$ & $\begin{array}{l}\text { Political } \\
\text { stability }\end{array}$ & $\begin{array}{c}\text { Government } \\
\text { effectiveness }\end{array}$ & $\begin{array}{l}\text { Regulatory } \\
\text { quality }\end{array}$ & Rule of law & $\begin{array}{l}\text { Control of } \\
\text { corruption }\end{array}$ \\
\hline \multirow{2}{*}{ Bulgaria } & Factor 1 & & & 0.915 & 0.851 & 0.907 & \\
\hline & Factor 2 & 0.909 & & & & & 0.760 \\
\hline \multirow{2}{*}{ Croatia } & Factor 1 & 0.859 & 0.717 & & & & 0.894 \\
\hline & Factor 2 & & & 0.890 & 0.717 & 0.776 & \\
\hline \multirow{2}{*}{ Czech Republic } & Factor 1 & 0.852 & 0.888 & & 0.770 & 0.833 & \\
\hline & Factor 2 & & & & & & 0.905 \\
\hline \multirow{2}{*}{ Estonia } & Factor 1 & 0.942 & & 0.763 & 0.935 & 0.845 & 0.905 \\
\hline & Factor 2 & & -0.957 & & & & \\
\hline \multirow{2}{*}{ Hungary } & Factor 1 & 0.883 & & & 0.946 & 0.868 & 0.792 \\
\hline & Factor 2 & & 0.956 & 0.730 & & & \\
\hline \multirow{2}{*}{ Latvia } & Factor 1 & & & 0.905 & 0.956 & 0.951 & 0.924 \\
\hline & Factor 2 & & 0.981 & & & & \\
\hline \multirow{2}{*}{ Lithuania } & Factor 1 & & 0.916 & 0.854 & 0.805 & 0.712 & \\
\hline & Factor 2 & 0.918 & & & & & 0.919 \\
\hline \multirow{2}{*}{ Poland } & Factor 1 & & & 0.878 & 0.773 & & \\
\hline & Factor 2 & 0.924 & & & & 0.825 & \\
\hline \multirow{2}{*}{ Romania } & Factor 1 & & & & 0.873 & 0.874 & 0.934 \\
\hline & Factor 2 & & -0.935 & & & & \\
\hline \multirow{2}{*}{ Slovakia } & Factor 1 & 0.876 & & 0.934 & 0.873 & 0.91 & \\
\hline & Factor 2 & & -0.873 & & & & 0.753 \\
\hline \multirow{2}{*}{ Slovenia } & Factor 1 & 0.869 & 0.844 & -0.758 & & & \\
\hline & Factor 2 & & & & & 0.905 & \\
\hline
\end{tabular}

\subsubsection{Regression coefficients}

By clustering institutions with the most significant annual variation (instability which can be associated with the institutional weakness in these countries as well as with a high transformation/adaptation potential), Factor 1 had a relevant statistical impact on economic growth which was lower compared to that on the labor market. The effects on economic growth were statistically relevant only in the case of Hungary (F1 including Government effectiveness, Regulatory quality, and Rule of law) and of Slovenia (F1 including Voice and accountability, Political stability, and Government effectiveness) (Table 2 and Table 3), while in terms of Employment rate, these were relevant in Bulgaria, Estonia, Hungary, Latvia, Lithuania, Poland and Slovenia (Table 4). 
Table 3: Regression coefficients for the econometric models with GDP growth rate as dependent variable

\begin{tabular}{|c|c|c|c|}
\hline & & $F_{1}$ & $F_{2}$ \\
\hline \multirow{3}{*}{ Bulgaria } & Regr. coeff. & 1.562 & $1.863^{*}$ \\
\hline & Std. coeff. & 0.314 & 0.374 \\
\hline & t-Statistic & 1.647 & 1.964 \\
\hline \multirow{3}{*}{ Croatia } & Regr. coeff. & 0.740 & $-2.056 * \star *$ \\
\hline & Std. coeff. & 0.231 & -0.641 \\
\hline & t-Statistic & 1.445 & -4.016 \\
\hline \multirow{3}{*}{$\begin{array}{l}\text { Czech } \\
\text { Republic }\end{array}$} & Regr. coeff. & -0.142 & -0.307 \\
\hline & Std. coeff. & -0.054 & -0.116 \\
\hline & t-Statistic & -0.247 & -0.537 \\
\hline \multirow{3}{*}{ Estonia } & Regr. coeff. & -0.919 & -1.788 \\
\hline & Std. coeff. & -0.167 & -0.325 \\
\hline & t-Statistic & -0.821 & -1.598 \\
\hline \multirow{3}{*}{ Hungary } & Regr. coeff. & $-0.876^{*}$ & $1.457^{\star \star}$ \\
\hline & Std. coeff. & -0.329 & 0.547 \\
\hline & t-Statistic & -1.956 & 3.254 \\
\hline \multirow{3}{*}{ Latvia } & Regr. coeff. & -1.326 & $2.263^{\star \star}$ \\
\hline & Std. coeff. & -0.237 & 0.405 \\
\hline & t-Statistic & -1.232 & 2.101 \\
\hline \multirow{3}{*}{ Lithuania } & Regr. coeff. & 0.487 & -0.722 \\
\hline & Std. coeff. & 0.098 & -0.145 \\
\hline & t-Statistic & 0.456 & -0.676 \\
\hline \multirow{3}{*}{ Poland } & Regr. coeff. & -0.498 & -0.263 \\
\hline & Std. coeff. & -0.310 & -0.164 \\
\hline & t-Statistic & -1.515 & -0.801 \\
\hline \multirow{3}{*}{ Romania } & Regr. coeff. & 0.808 & $1.811^{\star \star}$ \\
\hline & Std. coeff. & 0.194 & 0.434 \\
\hline & t-Statistic & 1.009 & 2.261 \\
\hline \multirow{3}{*}{ Slovakia } & Regr. coeff. & 0.039 & 0.511 \\
\hline & Std. coeff. & 0.012 & 0.160 \\
\hline & t-Statistic & 0.056 & 0.742 \\
\hline \multirow{3}{*}{ Slovenia } & Regr. coeff. & $1.188^{*}$ & -0.439 \\
\hline & Std. coeff. & 0.395 & -0.146 \\
\hline & t-Statistic & 1.997 & -0.738 \\
\hline
\end{tabular}

${ }^{*} p<0.10 ; * * p<0.05 ; * * * p<0.01$
Table 4: Regression coefficients for the econometric models with Employment rate as dependent variable

\begin{tabular}{|c|c|c|c|}
\hline & & $F_{1}$ & $F_{2}$ \\
\hline Bulgaria & $\begin{array}{l}\text { Regr. coeff. } \\
\text { Std. coeff. } \\
\text { t-Statistic }\end{array}$ & $\begin{array}{c}2.262^{\star \star} \\
0.659 \\
4.338\end{array}$ & $\begin{array}{l}-0,983^{*} \\
-0.286 \\
-1.886\end{array}$ \\
\hline Croatia & $\begin{array}{l}\text { Regr. coeff. } \\
\text { Std. coeff. } \\
\text { t-Statistic }\end{array}$ & $\begin{array}{l}-0.056 \\
-0.041 \\
-0.220\end{array}$ & $\begin{array}{l}0.684^{\star \star} \\
0.508 \\
2.705\end{array}$ \\
\hline $\begin{array}{l}\text { Czech } \\
\text { Republic }\end{array}$ & $\begin{array}{l}\text { Regr. coeff. } \\
\text { Std. coeff. } \\
\text { t-Statistic }\end{array}$ & $\begin{array}{l}0.260 \\
0.141 \\
0.697\end{array}$ & $\begin{array}{l}0.629 \\
0.343 \\
1.690\end{array}$ \\
\hline Estonia & $\begin{array}{l}\text { Regr. coeff. } \\
\text { Std. coeff. } \\
\text { t-Statistic }\end{array}$ & $\begin{array}{l}1.463^{\star \star *} \\
0.698 \\
6.721\end{array}$ & $\begin{array}{l}1.122^{\star \star \star} \\
0.535 \\
5.152\end{array}$ \\
\hline Hungary & $\begin{array}{l}\text { Regr. coeff. } \\
\text { Std. coeff. } \\
\text { t-Statistic }\end{array}$ & $\begin{array}{l}-3.732^{\star \star *} \\
-0.834 \\
-10.957\end{array}$ & $\begin{array}{l}-1.913^{\star * *} \\
-0.428 \\
-5.617\end{array}$ \\
\hline Latvia & $\begin{array}{l}\text { Regr. coeff. } \\
\text { Std. coeff. } \\
\text { t-Statistic }\end{array}$ & $\begin{array}{c}2.453^{\star * \star} \\
0.895 \\
10.124\end{array}$ & $\begin{array}{l}-0.505^{\star \star} \\
-0.184 \\
-2.085\end{array}$ \\
\hline Lithuania & $\begin{array}{l}\text { Regr. coeff. } \\
\text { Std. coeff. } \\
\text { t-Statistic }\end{array}$ & $\begin{array}{l}0.392^{\star} \\
0.188 \\
1.773\end{array}$ & $\begin{array}{l}1.782^{\star \star \star} \\
0.854 \\
8.062\end{array}$ \\
\hline Poland & $\begin{array}{l}\text { Regr. coeff. } \\
\text { Std. coeff. } \\
\text { t-Statistic }\end{array}$ & $\begin{array}{l}1.004^{\star \star} \\
0.625 \\
3.801\end{array}$ & $\begin{array}{l}-0.333 \\
-0.207 \\
-1.260\end{array}$ \\
\hline Romania & $\begin{array}{l}\text { Regr. coeff. } \\
\text { Std. coeff. } \\
\text { t-Statistic }\end{array}$ & $\begin{array}{l}-0.859 \\
-0.342 \\
-1.688\end{array}$ & $\begin{array}{l}-0.335 \\
-0.134 \\
-0.658\end{array}$ \\
\hline Slovakia & $\begin{array}{l}\text { Regr. coeff. } \\
\text { Std. coeff. } \\
\text { t-Statistic }\end{array}$ & $\begin{array}{l}-0.148 \\
-0.163 \\
-0.849\end{array}$ & $\begin{array}{l}0.406 * * \\
0.447 \\
2.332\end{array}$ \\
\hline Slovenia & $\begin{array}{l}\text { Regr. coeff. } \\
\text { Std. coeff. } \\
\text { t-Statistic }\end{array}$ & $\begin{array}{l}-1.331 \text { *** } \\
-0.698 \\
-4.483\end{array}$ & $\begin{array}{l}0.105 \\
0.055 \\
0.355\end{array}$ \\
\hline
\end{tabular}

${ }^{*} p<0.10 ; * * p<0.05 ; * \star * p<0.01$

With a different F1 structure from one country to another, the linkages between institutional dynamics and economic resilience are obviously extremely heterogenous. However, we may observe that there are some similarities between Bulgaria, Estonia, Hungary, Latvia and Lithuania in terms of three common components which had an impact on the labor market dynamic: Government effectiveness, Regulatory quality, and Rule of law. Voice and accountability is another statistically relevant factor in terms of impact; nevertheless, it is associated with a different group of countries: Estonia, Hungary, Poland and Slovenia. Government effectiveness and Rule of law are generally identified as elements whose dynamics influences economic resil- 
ience in most of the countries under analysis. As far as the F2 factor is concerned, by clustering lower variation institutions, the impact on the GDP growth rate proves statistically significant in a number of countries: Bulgaria, Croatia, Hungary, Latvia and Romania (Table 3); as far as Employment rate is concerned, it is statistically significant in Bulgaria, Croatia, Estonia, Hungary, Latvia, Lithuania and Slovakia (Table 4). However, this time, the more relevant indicators were Political stability, Government effectiveness, and Control of corruption.

It is also important to note the fact that in 9 countries, the impact of the institutional dynamic was negative either on the GDP/ Employment rate or on both variables (Table 3 and Table 4) although not statistically significant in all cases, as seen above. The most serious negative relations on the GDP rate were identified in Croatia, Hungary and Slovenia, while the most serious negative relations on the Employment rate were identified in Hungary. Thus, with the specific statistical analysis limitations in mind, we may assume the fact that, as a result of the institutional system's resilient adaptability, the institutional dynamics in these countries has had a rather negative than transformative impact on economic resilience.

Moreover, during the period under analysis (1996-2019), CEECs went through various fundamental transformations (economic, social, legislative, institutional) and, at the same time, became acquainted with the integration process dynamics. Following the accession waves of 2004 and 2007, legislation adaptation to European norms generated a convergence process. However, as a consequence of the 2008/2009 crisis, of the refugee crisis, of the EU Eastern border conflict, macroeconomic instability, corruption intensification, violation of norms and regulations, political instability, excessive bureaucracy, protests, etc. became more and more apparent and further deepened economic and institutional vulnerabilities in this part of Europe. Also, in these countries, the attempt to adapt the new democratic values to the lingering systems of former autocratic regimes has limited the efficiency of growth policies.

\section{Conclusions}

In the context of the crisis generated by the COVID-19 pandemic, the analysis of resilience and of the factors which influence it is a key topic at the international level. This pandemic seriously challenges the idea of governance and the governments' capacity to manage change in highly uncertain conditions (Țiclău, Hințea and Andrianu, 2020). The 2020 Rule of Law report of the European Commission draws attention to the fact that the current health crisis represents a 'stress test for rule of law resilience' (European Commission, 2020b, p. 6), while the OECD report (2020) supports the major role that some resilient institutions have in 'navigating' through the crisis. Hence, the need to seriously consider the significance that institutional arrangements have in consolidating economic resilience in this period becomes urgent.

The paper highlights the influence of institutional factors and of institutions' dynamics, in particular, on the economic resilience of CEECs - EU Member States. On 
the one hand, we have aimed to analyze whether institutional factors have influenced economic resilience and to identify those institutions which have had a stronger influence on economic resilience; on the other hand, we have aimed to emphasize how institutional dynamics influences economic resilience.

Our results are in line with previous studies (European Central Bank, 2016; Sonderman, 2017), thus confirming the influence of institutional factors on economic resilience. Our panel data estimations show the statistically significant determinism of Political stability, Rule of law, and Control of corruption on the GDP growth rate. Regarding the Employment rate, the institutional variables Voice and accountability, and Political stability have a negative influence on it, while Government effectiveness, Rule of law, and Control of corruption have a positive influence. We note the fact that the Rule of law and Control of corruption influence both variables measuring the economic resilience in our study. This aspect essentially shows that, to a great extent, economic resilience depends on the Rule of law and Control of corruption. Moreover, in the literature, as well as in official documents, both institutional factors are referred to in close relation with resilience issues. The importance of the Rule of law in consolidating economic resilience is the focus of numerous studies and reports (Ebbesson, 2010; European Commission, 2020b) and, as far as corruption is concerned, we may refer, for example, to Osei's empirical study (2011) which demonstrates that corruption, closely related to the quality of government, and as an obvious effect of poor governance, negatively influences economic resilience.

Also, the estimations we have reached support the fact that, in many CEECs, the institutional factors selected after PCA have a higher significant statistical influence on the Employment rate compared to the GDP growth rate, thus demonstrating that the labor market in these countries is more sensitive to the quality of the institutional environment and, at the same time, more resilient. We believe this conclusion is very important given the role that the labor market has in ex-post resilience (European Central Bank, 2016) or, put otherwise, in the recovery period.

The analysis of country-specific characteristics has enabled us to identify the interdependencies between economic resilience and institutions' dynamics. The research has essentially emphasized the institutional instability and the heterogeneity of interdependencies with the GDP growth rate and Employment rate as indicators used to reflect resilience performance; for this reason, we are unable to identify a pattern for these interdependencies. The bottom line is that, in many of the countries under analysis, institutional instability had a negative effect on economic resilience, which means that CEECs' institutions are rather fragile, with a low resilience capacity and ability to adapt/recover in crisis conditions or to support transformative processes in their economies.

From the resilience-based policies' point of view, firstly, the need to have a strong institutionalist perspective, focused on those institutions which are particularly relevant in increasing resilience performance in these countries, is urgent. Secondly, the heterogeneity of conditionalities identified in our analysis draws attention to the 
risk implied by using a standard approach, common to all countries, and to reducing institutionalist approaches in these states to the potential convergence generated by integration. Consequently, the 'recovery and resilience' concerns at the EU level must go beyond investment and development programs based on common objectives and principles, as the current NRRPs, key tools for postpandemic recovery strategy, seem to reflect. The establishment of a framework conducive to economic recovery through these plans, together with a coordination of economic and fiscal-budgetary policies, should not deviate from the recommendations within the European Semester, in response to the need to reduce territorial vulnerabilities, so that the EU Recovery and Resilience Mechanism to achieve as well as possible the purpose for which it was created. In connection with our research, these plans must be essentially aimed at improving the quality of the institutional environment so as to generate a proper context for increasing resilience capacity. Moreover, further in-depth analyses may lead to the identification of institutions which are more adaptable and have a higher potential to condition economic resilience.

\section{References:}

1. Acemoglu, D., Johnson, S. and Robinson, J., 'Institutions as the Fundamental Cause of Long-Run Growth', 2004, NBER Working Paper, No. 10481, [Online] available at https:// www.nber.org/system/files/working_papers/w10481/w10481.pdf, accessed on August 15, 2021.

2. Acemoglu, D., Johnson, S., Robinson, J. and Thaicharoen, Y., 'Institutional Causes, Macroeconomic Symptoms: Volatility, Crises and Growth', 2003, fournal of Monetary Economics, vol. 50, no. 1, pp. 49-123.

3. Anthony, E.J., 'The Syndrome of the Psychologically Invulnerable Child', in Anthony, E.J. and Koupernik, C., (eds), The Child in His Family: Children at Psychiatric Risk, New York: Wiley, 1974, pp. 529-545.

4. Banică, A., Eva, M., Corodescu-Roșca, E., Ibănescu, B.C., Opria, A.M. and Pascariu, G.C., 'Towards Smart(er) Resilient Cities. Evidences from Romanian Urban Areas', 2020, Geografie, vol. 125, no. 4, pp. 397-422.

5. Batabyal, A.A., 'The Concept of Resilience: Retrospect and Prospect', 1998, Environment and Development Economics, vol. 3, no. 2, pp. 221-262.

6. Bourbeau, P., 'Resilience and International Politics: Premises, Debates, Agenda', 2015, International Studies Review, vol. 17, no. 3, pp. 374-395.

7. Briguglio, L., Cordina, G., Farrugia, N. and Vella, S., 'Economic Vulnerability and Resilience Concepts and Measurements', 2008, WIDER Research Paper, No. 2008/55, [Online] available at https://www.econstor.eu/bitstream/10419/45146/1/571437761.pdf, accessed on August 16, 2021.

8. Bristow, G., 'Resilient Regions: Re-'place'ing Regional Competitiveness', 2010, Cambridge Journal of Regions, Economics and Society, vol. 3, no. 1, pp. 153-167.

9. Bristow, G., Healy, A., Norris, L., Wink, R., Kafkalas, G., Kakderi, C., Espenberg, K., Varblane, U., Sepp, V., Sagan, S., Masik, G., Sensier, M., Harding, A., Swash, A. and Carey, H., 
'ECR2. Economic Crisis and the Resilience of Regions', 2014, [Online] available at https:// www.espon.eu/sites/default/files/attachments/ESPON_Territorial-Observation_12-CrisisResilience.pdf, accessed on August 16, 2021.

10. Carpenter, S., Walker, B., Anderies, J.M. and Abel, N., 'From Metaphor to Measurement: Resilience of What to What?', 2001, Ecosystems, vol. 4, no. 8, pp. 765-781.

11. Cellini, R. and Torrisi, G., 'Regional Resilience in Italy: A Very Long-Run Analysis', 2014, Regional Studies, vol. 48, no. 11, pp. 1779-1796.

12. Cheshire, L., Esparcia, J. and Shucksmith, M., 'Community Resilience, Social Capital and Territorial Governance', 2015, Ager. Journal of Depopulation and Rural Development Studies, no. 18, pp. 7-38.

13. Di Caro, P., 'Regional Recessions and Recoveries in Theory and Practice: A Resilience-based Overview', 2014, MPRA Paper, No. 60300, University Library of Munich, Germany, [Online] available at https://mpra.ub.uni-muenchen.de/60300/1/MPRA_paper_60300.pdf, accessed on August 29, 2021.

14. Ebbesson, J., 'The Rule of Law in Governance of Complex Socio-Ecological Changes', 2010, Global Environmental Change, vol. 20, no. 3, pp. 414-422.

15. European Central Bank, 'Increasing Resilience and Long-Term Growth: The Importance of Sound Institutions and Economic Structures for Euro Area Countries and EMU', 2016, ECB Economic Bulletin, Issue 5, Article 3, [Online] available at https://www.ecb.europa.eu/pub/ pdf/other/eb201605_article03.en.pdf, accessed on August 15, 2021.

16. European Commission, 'The European Green Deal, Communication from the Commission to the European Parliament, the European Council, the Council, the European Economic and Social Committee and the Committee of the Regions', COM(2019) 640 final, 2019, [Online] available at https://ec.europa.eu/info/sites/default/files/european-green-deal-com munication_en.pdf, accessed on August 29, 2021.

17. European Commission, 'Europe's Moment: Repair and Prepare for the Next Generation, Communication from the Commission to the European Parliament, the European Council, the Council, the European Economic and Social Committee and the Committee of the Regions', COM/2020/456 final, 2020a, [Online] available at https://eur-lex.europa.eu/le gal-content/EN/TXT/?qid=1590732521013\&uri=COM\%3A2020\%3A456\%3AFIN, accessed on August 29, 2021.

18. European Commission, '2020 Rule of Law Report. The Rule of Law Situation in the European Union', $\operatorname{COM}(2020) 580$ final, 2020b, [Online] available at https://ec.europa. eu/info/sites/default/files/communication_2020_rule_of_law_report_en.pdf, accessed on August 14, 2021.

19. Fingleton, B., Garretsen, H. and Martin, R., 'Recessionary Shocks and Regional Employment', 2012, Journal of Regional Science, vol. 52, no. 1, pp. 109-133.

20. Foster, K.A., 'A Case Study Approach to Understanding Regional Resilience', 2007, Working Paper 2007-08, [Online] available at https://www.econstor.eu/obitstream/10 419/59413/1/592535347.pdf, accessed on August 14, 2021.

21. Frunză, R., 'The Role of the Institution of Property in the Economic Transformation and Development Process in Central and Eastern Europe', 2011, Transformations in Business \& Economics, vol. 10, no. 2(23), Suppl. B, pp. 33-48. 
22. Healy, A., 'Strengthening Economic Resilience', 2020, [Online] available at https://www. wcpp.org.uk/wp-content/uploads/2020/03/Strengthening-economic-resilience-.pdf, accessed on August 20, 2021.

23. Hill, E.W., Wial, H. and Wolman, H., 'Exploring Regional Economic Resilience', 2008, Working Paper 2008-04, [Online] available at https://escholarship.org/uc/item/7fq4n2cv, accessed on August 12, 2021.

24. Holling, C.S., 'Resilience and Stability of Ecological Systems', 1973, Annual Review of Ecology and Systematics, vol. 4, pp. 1-23.

25. Iacobuță, A.O., Asandului, L. and Cautisanu, C., 'Assessment of Economic Growth in Romania. Is It a Sustainable One?', 2020, European fournal of Sustainable Development, vol. 9, no. 3, pp. 513-537.

26. Iacobuță, A.O., Costurile de tranzacție - o abordare instituționalistă (Transaction Costs - An Institutionalist Approach), Iași: Alexandru Ioan Cuza University Publishing House, 2012.

27. Joint Research Centre, European Commission, 'The Challenge of Resilience in a Globalized World', 2015, [Online] available at https://ec.europa.eu/jrc/sites/default/files/jrc-resil ience-in-a-globalised-world_en.pdf, accessed on August 25, 2021.

28. Kitsos, A. and Bishop, P., 'Economic Resilience in Great Britain: The Crisis Impact and Its Determining Factors for Local Authority Districts', 2018, The Annals of Regional Studies, vol. 60, pp. 329-347.

29. Linnell, M., 'Citizen Response in Crisis: Individual and Collective Efforts to Enhance Community Resilience', 2014, Human Technology, vol. 10, no. 2, pp. 68-94.

30. Magoni, M., 'Resilience Thinking and Urban Metabolism in Spatial Planning: Which Possible Integrations', 2017, City, Territory and Architecture, vol. 4, no. 19, pp. 1-8.

31. Martin, J.C. and Roman, C., 'The Effects of COVID-19 on EU Federalism', 2021, Eastern Journal of European Studies, vol. 12 (Special Issue), pp. 126-148.

32. Martin, R. and Sunley, P., 'On the Notion of Regional Economic Resilience: Conceptualization and Explanation', 2015, fournal of Economic Geography, vol. 15, pp. 1-42.

33. North, D.C., Institutions, Institutional Change, and Economic Performance, New York: Cambridge University Press, 1990.

34. OECD, Development Co-operation Report 2020: Learning from Crises, Building Resilience, Paris: OECD Publishing, 2020.

35. Official Journal of the European Union (1990-2021), [Online] available at https://eurlex.europa.eu/search.html? scope=EURLEX\&text=resilience \&lang=en\&type=quick\&qid =1630412952461, accessed on August 26, 2021.

36. Osei, P.D. 'The Nexus between Economic Resilience and Corruption', 2011, [Online] available at https:/www.um.edu.mt/library/oar/bitstream/123456789/41721/2/The_nexus_be tween_economic_resilience_and_corruption.pdf, accessed on August 26, 2021.

37. Pascariu, G.C. and Țigănașu, R., 'Integration, Growth and Core-Periphery Pattern in EU's Economy: Theoretical Framework and Empirical Evidences', in Pascariu, G.C. and Duarte, A. (eds.), Core-Periphery Patterns across the European Union: Case Studies and Lessons from Eastern and Southern Europe, Emerald Publishing, 2017, pp. 23-88.

38. Pintilescu, C. and Viorică, D., 'Current Methodological Approaches in Economic Resilience Analysis. Empirical Findings in the EaP Countries', in Rouet, G. and Pascariu, G.C. (eds.), 
Resilience and the EU's Eastern Neighbourhood Countries. From Theoretical Concepts to a Normative Agenda, Springer, 2019, pp. 321-348.

39. Reggiani, A., De Graaff, T. and Nijkamp, P., 'Resilience: An Evolutionary Approach to Spatial Economic Systems', 2002, Networks and Spatial Economics, vol. 2, p. 211-229.

40. Samarasinghe, T., 'Impact of Governance on Economic Growth', University Library of Munich, Germany, 2018, [Online] available at MPRA_paper_89834.pdf (uni-muenchen.de), accessed on August 25, 2021.

41. Sirowy, L. and Inkeles, A., 'The Effects of Democracy on Economic Growth and Inequality: A Review', 1990, Studies in Comparative International Development, vol. 25, no. 1, pp. 126-157.

42. Sjöstedt, M. 'Resilience Revisited: Taking Institutional Theory Seriously', 2015, Ecology and Society, vol. 20, no. 4, art. 23.

43. Suzuki, S. and Nijkamp, P., Regional Performance Measurement and Improvement, Singapore: Springer, 2017.

44. Swanstrom, T., Chapple, K. and Immergluck, D., Regional Resilience in the Face of Foreclosures: Evidence from Six Metropolitan Areas, Berkeley, CA: Institute of Urban and Regional Development, 2009.

45. Socoliuc, O.R., Dinamica economică în viziunea instituționalistă, Iași: Ed. Universității Alexandru Ioan Cuza, 2014.

46. Sonderman, D., 'Towards More Resilient Economies: The Role of Well-Functioning Economic Structures', 2017, CEPS Working Documents, No. 2017/03, [Online] available at https://www.ceps.eu/download/publication/?id=9808\&pdf=WD\%202017_03\%20DSonder mann\%20ResilientEconomies.pdf, accessed on August 12, 2021.

47. Țiclău, T., Hințea, C. and Andrianu, B., 'Adaptive and Turbulent Governance. Ways of Governing that Foster Resilience. The Case of the COVID-19 Pandemic', 2020, Transylvanian Review of Administrative Sciences, Special Issue, pp. 167-182.

48. Țigănașu, R., Pascariu, G.C. and Baciu, L., 'Conditionalities in the Recovery Process of Economic Growth and Convergence in Central and Eastern European Countries', 2014, Transformations in Business \& Economics, vol. 13, no. 3C (33C), pp. 389-409.

49. Vlăsceanu, L., Politică şi dezvoltare. România încotro? (Politics and Development. Romania Where To?), București: Trei, 2001. 


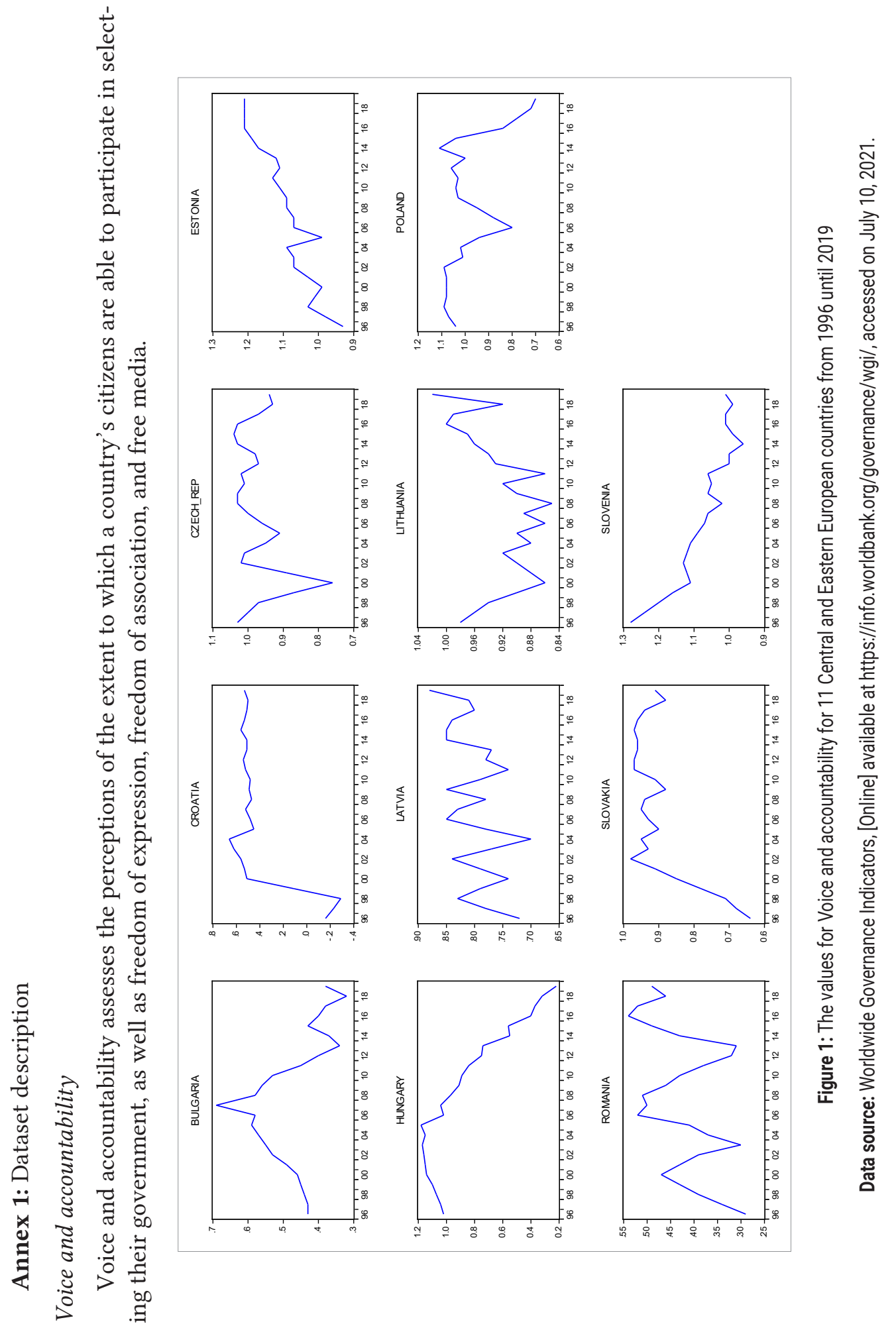




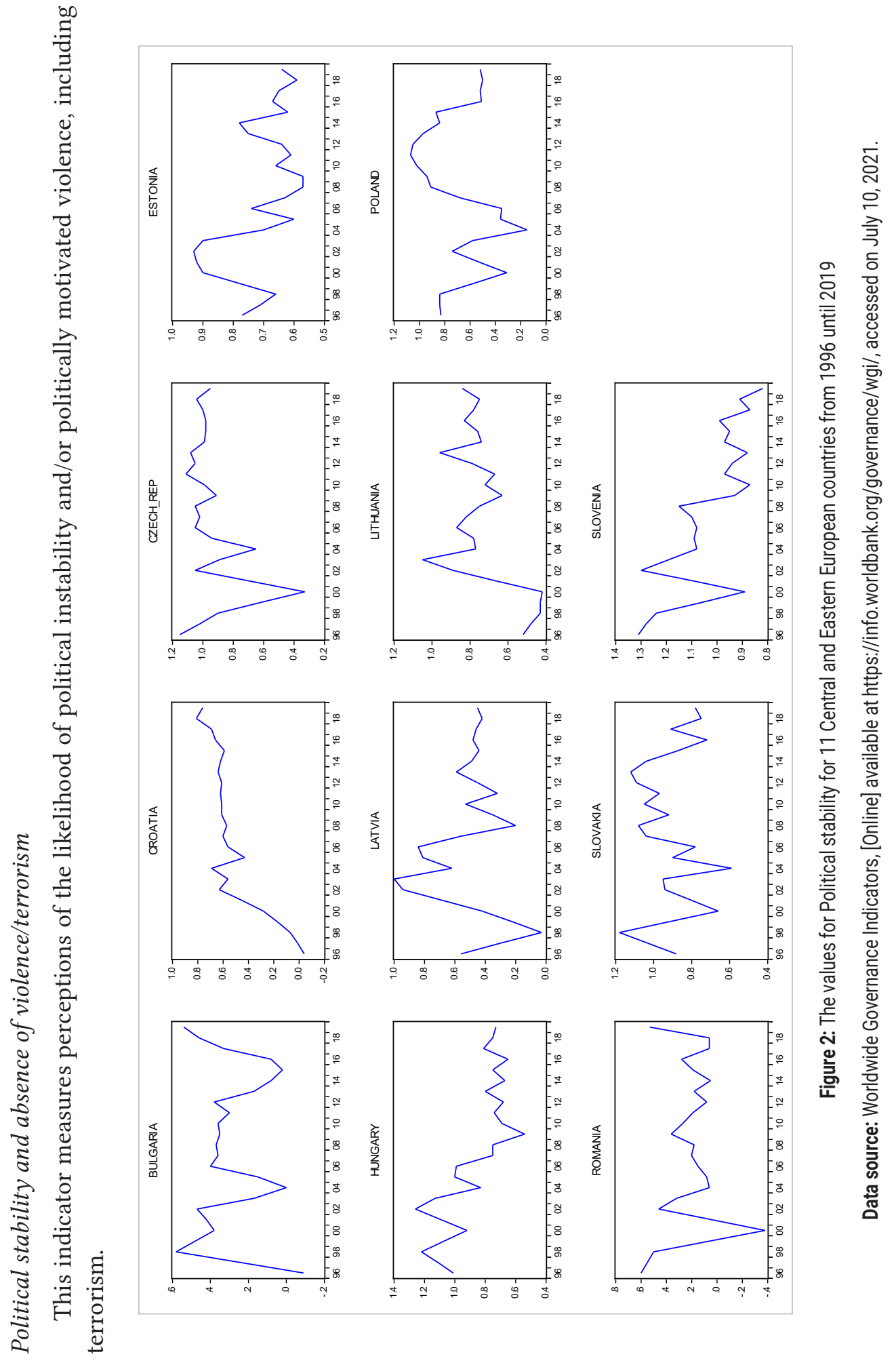




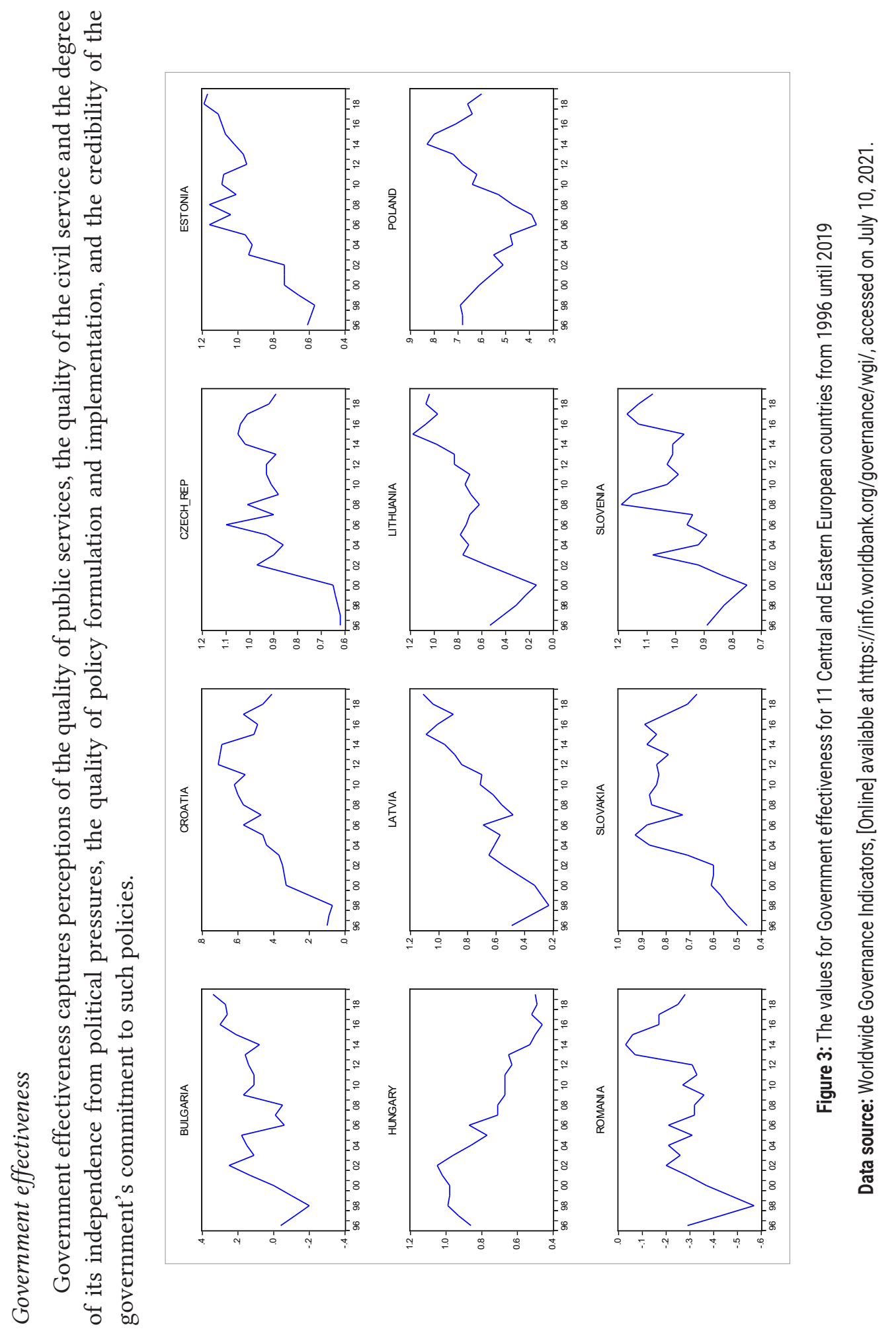




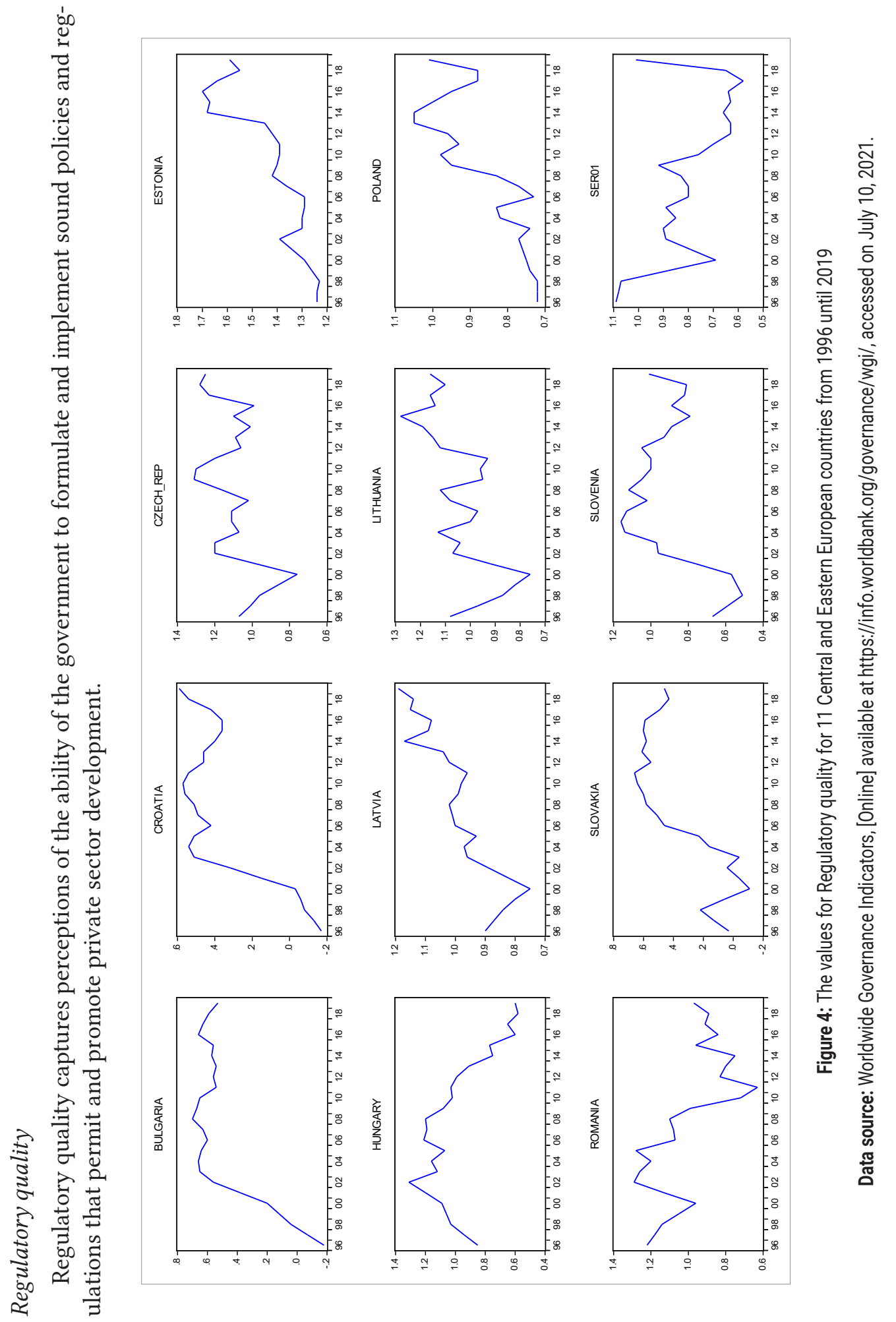




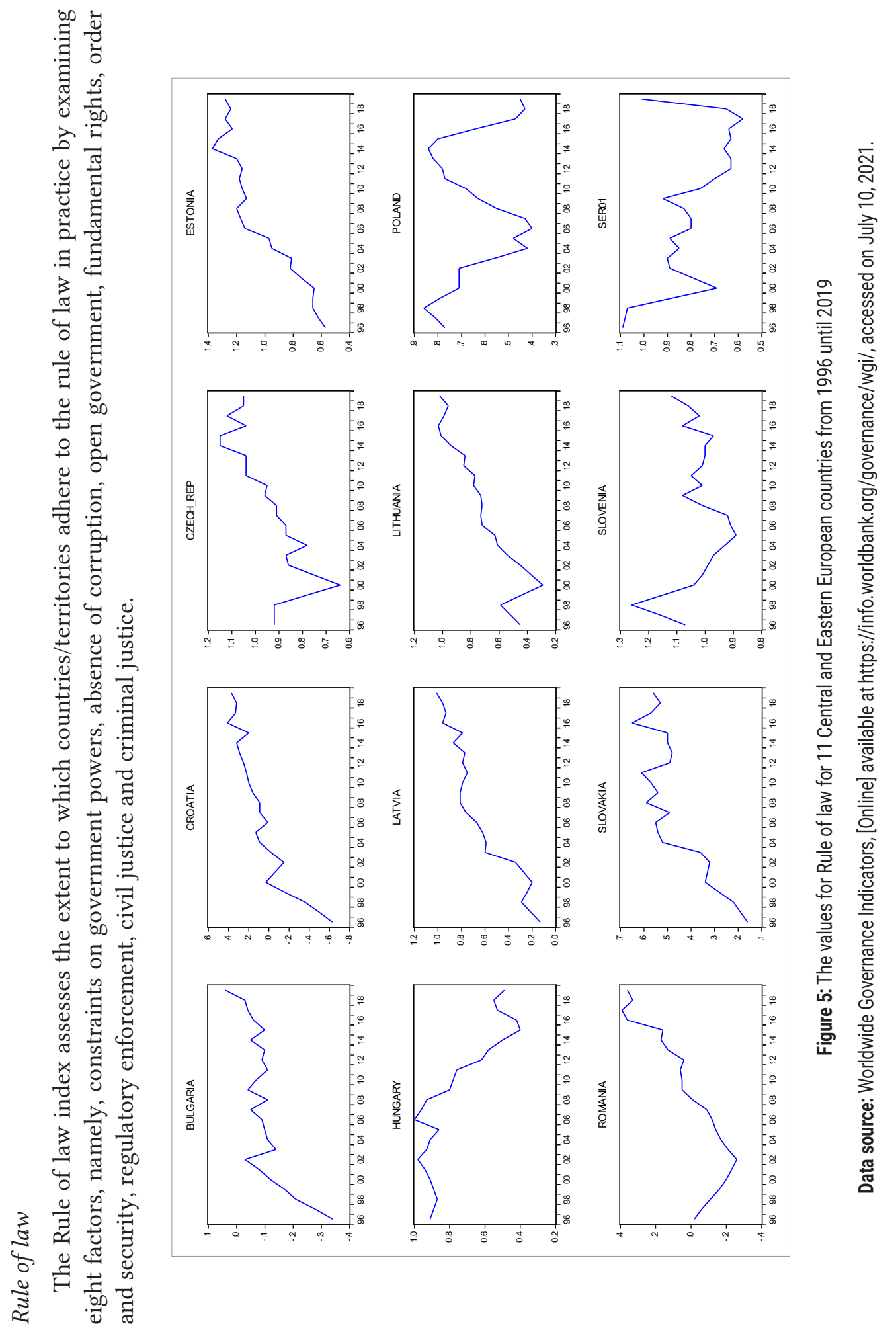




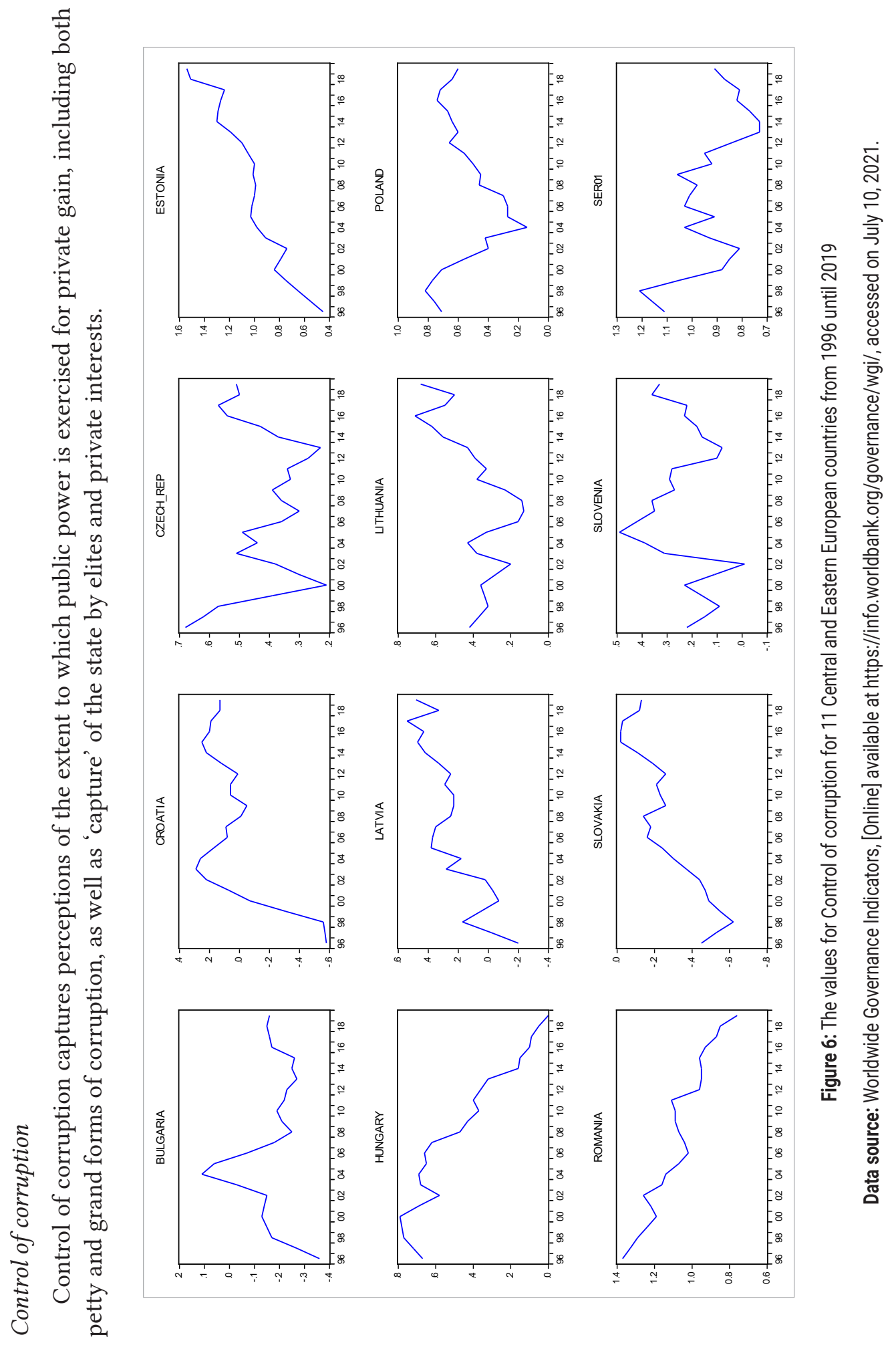



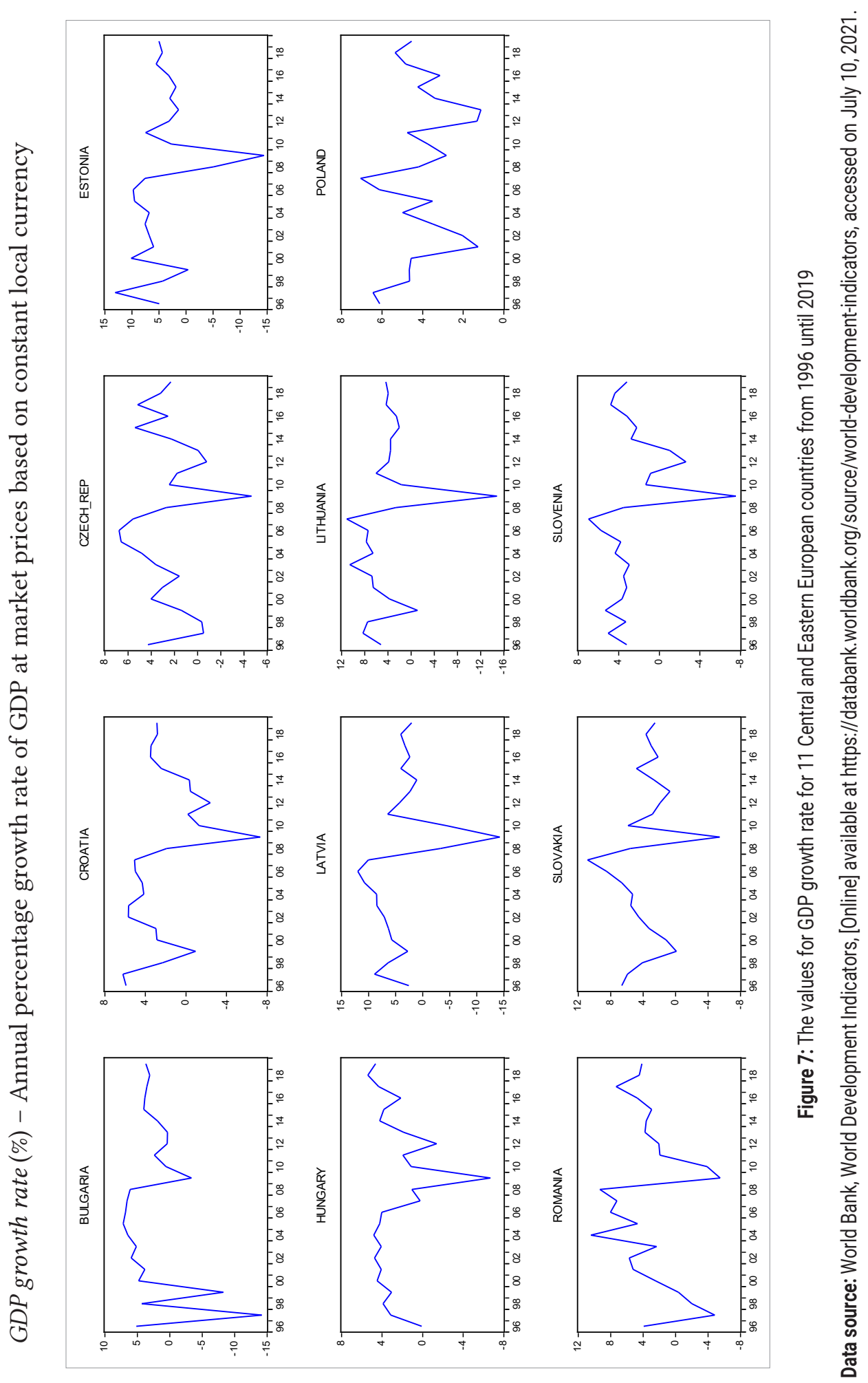

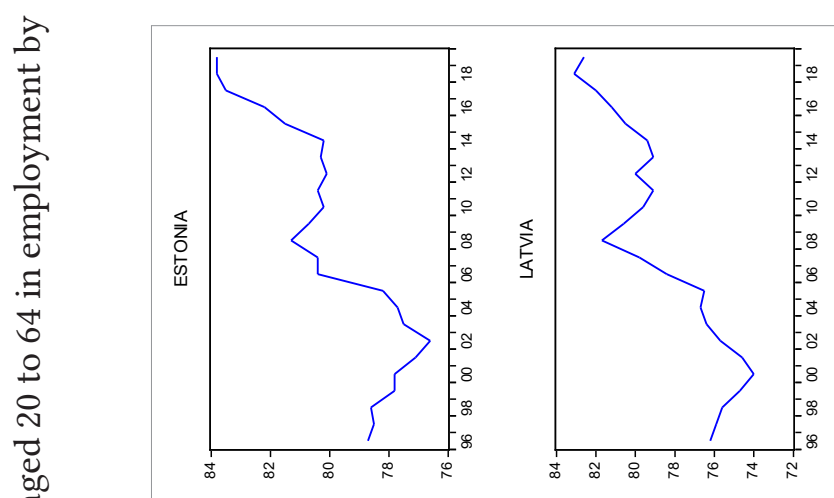

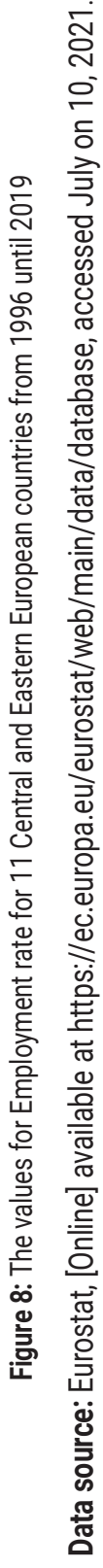
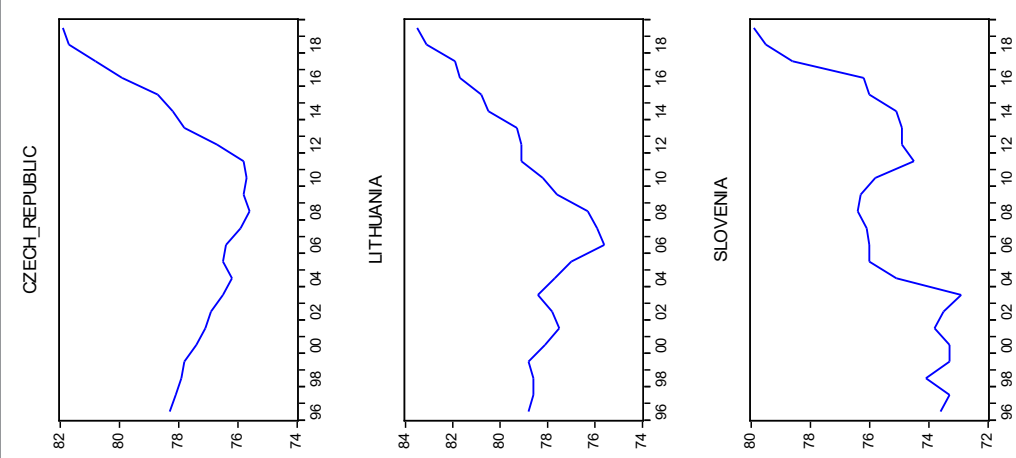

合
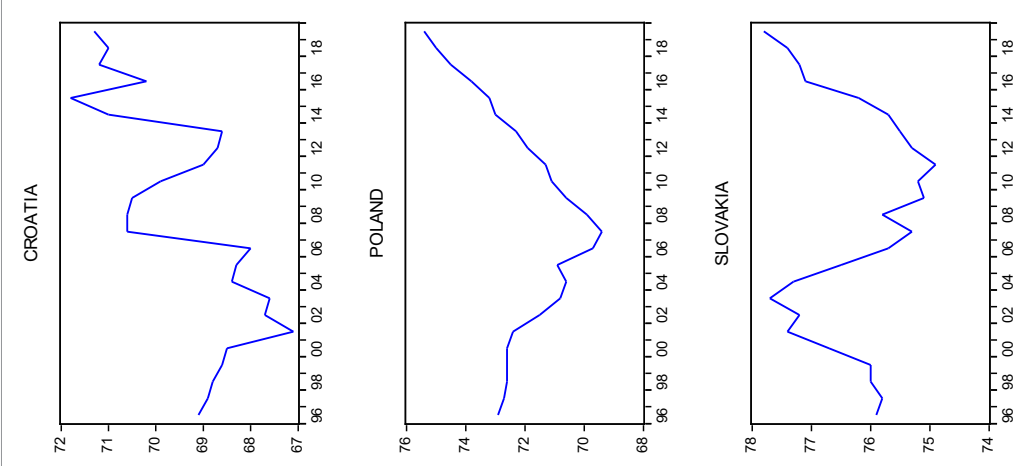

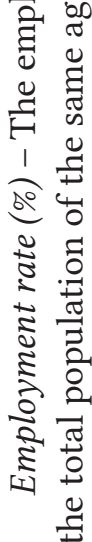
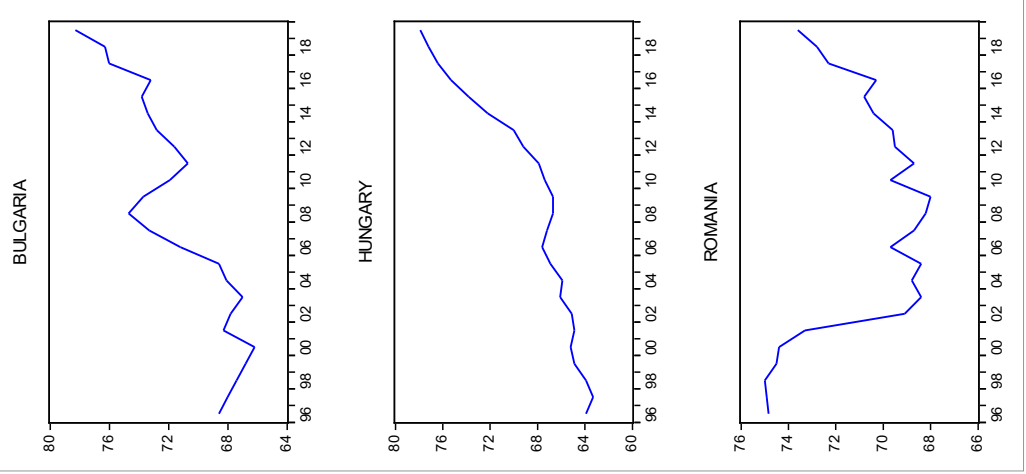